\title{
Effect of Different Plastic Sheet Coverings and Pruning Time on Yield and Yield Components of Table Grape "cv. Superior"
}

\author{
Aly, M. A.; Thanaa M. Ezz.; Rehab M. Awad and A. Abou-Elmaaty \\ Fac. Agric., Saba Basha, Plant Production Department, Alex. Univ.
}

Received: $23 / 3 / 2015$

\begin{abstract}
This study was carried out during two successive seasons in 2007 and 2008 on five years old "cv. Superior" grape cultivar in a private vineyard at El-Noubarya city, Behaira Governorate, Egypt. The vines were grown in sandy soil with spacing of $2 \mathrm{~m}$ within rows and $3 \mathrm{~m}$ between rows under drip irrigation system and trained to cane pruning under baron trellis system. The main factor was the three pruning times [(1st December (P1), 15th December (P15) and $30^{\text {th }}$ December (P30)] carried during dormant season to ten canes per vine with 12 nodes per cane. Four renewal spurs ( 2 nodes) were tretained per vine, while the sub main factor was four mulching treatments with sheet cover sleeves air white plastic (WSCT), air yellow plastic (YSCT), soil white plastic (WSCS) and soil yellow plastic (YSCS). The control was the rest of the field (no mulch with pruning $20^{\text {th }}$ December).The (P30YSCS) and (P30WSCS) treatments gave the highest yield ( $\mathrm{kg} / \mathrm{vine})$ in the first and second seasons compared with control treatment. Also the treatments (P1YSCS), (P1WSCS), (P1YSCT) and (P1WSCT) gave the lowest value of yield as compared with control. All treatments significantly decreased number of berries/cluster in both seasons, except the treatments (P1YSCS), (P1WSCS), (P15YSCS), (P15WSCS) and the control. The increasing of cluster length and decreasing of berries number in the treatments (P1YSCT), (P1WSCT), (P15YSCT), (P15WSCT), (P30YSCT) and (P30WSCT) caused a significant reduction in cluster compactness as compared with control treatment. Furthermore, increasing of cluster compactness significantly under the treatments (P1YSCS), (P1WSCS), (P15YSCS), (P15WSCS), (P30YSCS), (P30WSCS) and the control caused by decreasing cluster length and increasing berries number compared with all treatments. Accumulation of high temperatures by (P1YSCT), (P1WSCT), (P15YSCT), (P15WSCT), (P30YSCT) and (P30WSCT) increased total sugars in both seasons compared with control treatment, but the treatments (P1YSCS), (P1WSCS), (P15YSCS), (P15WSCS), (P30YSCS) and (P30WSCS) did not affect total sugars compared with control treatment.
\end{abstract}

\section{INTRODUCTION}

The grapevine is one of the most important crop plants of the world. A grape is the fleshy, nonclimacteric fruit that grows on the perennial and deciduous woody vines of the family Vitaceae. Grapes grow in clusters of 6 to 300, and can be black, blue, golden, green, purple, red, pink, brown, peach or white. They can be eaten raw or used for making jam, grape juice, jelly, wine, grape seed oil and raisins (are the dried fruit of the grapevine). Cultivation of grapevines occurs in vineyards, and is called viticulture. Fresh table grapes are stored for fairly long duration under refrigeration (Asker et al., 1987). Plasticulture techniques use wavelength selective polyethylene mulch and clear polyethylene to trap solar energy, raise soil and air temperatures, and thereby advance the harvest season of row crops (Gaye et al., 1992a and b; Alexander and Clough, 1998; Bowen, 1998; Jenni et al., 1998). The transmissivity coefficients of the yellow plastic film were equal to $86.3 \%$ in the solar wavelength range (300-2500 nm) (Vox et al., 2014). Row covers also shield plants from wind which can disturb leaf display (Bowen and Frey, 2002) and reduce stomatal conductance (Caldwell, 1970). Although enclosing whole vineyard blocks or rows in polyethylene film has been used successfully to advance table grape harvest (Novello et al., 1999 and 2000). Covering a vineyard will modify the solar radiation characteristics (Smart, 1985 and Reynolds et al., 1996), protect the yields from rainfall on Thomson seedless grape cultivar in Australia and on red globe variety in California-USA (Anonymous, 2009 and Liberman, 2009) and, consequently, creates changes in the microclimate (photosynthetically active radiation, air temperature, humidity and wind speed) at the cluster level. The modification of the vineyard microclimate has direct effect on the plant water status (Katerji et al., 1994; Heilman et al., 1996), on the gaseous exchanges (Naor et al., 1994; Trambouze and Voltz, 2001), on the response of the crop to soil water depletion (Winkel and Rambal, 1990), and has great impact on the grape yield and quality (Smart, 1985). The choice of the plastic film becomes strategic not only to protect the vineyard against environmental hazards but also to sustain the grape production under abiotic stress (Vox et al., 2012). Pruning is an obvious management technique developed to regulate the balance between fruit production and vegetative growth of grapevines, also influencing bud behaviour and bud fertility (El-Hammady and Abdel Hamid, 1995; Howell and Strieglar, 1998; Ali et al., 2000; Omar and Abdel-Kawi, 2000). Pruning severity is influenced by the bearing nature and physiology of such grape vine cultivar. It is also well demonstrated that Roumi, Flame and Rouby seedless are pruned to spure system, since their fruitful buds are located at the basal part of the canes. On the other hand, Thompson seedless and Superior grapes are bearing unfruitful buds at the basal part of the canes, therefore, it have to prune to cane system (Shahein et al., 1998; Ali et al., 2000). Young vines bear few or even no fruitful buds; yet, older ones have healthy vegetative growth and produced normal crop needs of more carbohydrates than assimilated by the leaves at the first stage of development. A large accumulated carbohydrate in several parts of the vine, especially permanent wood of the trunk, arms, and canes may influence bud formation, bud burst, and bud fruitfulness, (Kliewer, 1967; ElShahat, 1992; Bowen and Kliewer, 1990; Ali et al., 2000). Various pruning systems are used for table grape 
cultivars, namely spur ( $2-3$ buds), half-cane ( $6-8$ buds) and cane (14-16 buds) systems, depending on the cultivar and region. Fruitful cultivars are spure pruned while less fruitful cultivars are half-cane or cane pruned. The objectives of this study were to investigate the effects of different air and soil plastic sheet coverings and pruning times on yield, physical and chemical components of berries of table grape "cv. Superior ".

\section{MATERIALS AND METHODS}

The present study was conducted during the two seasons of 2007 and 2008 in a private vineyard of "Superior" grape cultivar at El-Noubarya city, Behaira Governorate, Egypt. The vines were grown in a sandy soil (Tables 1 and 2) under drip irrigation system (Table 3 ), and trained to cane pruning under baron trellis system.

Table (1): PH, soluble ions and calculated SAR of saturation paste extracts.

\begin{tabular}{|c|c|c|c|c|c|c|c|c|c|c|c|}
\hline \multirow{2}{*}{$\begin{array}{l}\text { Soil depth } \\
\quad \text { (cm) }\end{array}$} & \multirow{2}{*}{$\mathbf{P H}$} & \multirow{2}{*}{$\begin{array}{c}\text { EC } \\
\mathrm{dS} / \mathrm{m}\end{array}$} & \multicolumn{8}{|c|}{ Soluble Salts (meq/l) } & \multirow[b]{2}{*}{ SAR } \\
\hline & & & $\mathrm{Ca}^{++}$ & $\mathbf{M g}^{++}$ & $\mathrm{Na}^{+}$ & $\mathbf{K}^{+}$ & $\mathrm{CO}_{3}^{--}$ & $\mathrm{HCO}_{3}^{-}$ & $\mathrm{CL}^{-}$ & SO4-- & \\
\hline $0-30 \mathrm{~cm}$ & 7.77 & 0.63 & 1.5 & 1.4 & 3.3 & 0.1 & 0.0 & 1.2 & 3.2 & 1.9 & 2.7 \\
\hline $30-60 \mathrm{~cm}$ & 7.34 & 0.61 & 1.2 & 1.2 & 3.1 & 0.1 & 0.0 & 1.0 & 2.9 & 1.7 & 2.5 \\
\hline
\end{tabular}

Table (2): Soil macro and micronutrients content and mechanical analysis.

\begin{tabular}{|c|c|c|c|c|c|c|c|c|c|c|c|}
\hline \multirow{2}{*}{$\begin{array}{l}\text { Soil depth } \\
\text { (cm) }\end{array}$} & \multicolumn{3}{|c|}{$\begin{array}{l}\text { Macronutrient } \\
\text { (ppm) }\end{array}$} & \multicolumn{4}{|c|}{$\begin{array}{l}\text { DTPA-extractable micro- } \\
\text { Nutrients (ppm) }\end{array}$} & \multicolumn{3}{|c|}{$\begin{array}{l}\text { Soil mechanical } \\
\text { analysis (\%) }\end{array}$} & \multirow[t]{2}{*}{$\begin{array}{c}\text { Soil } \\
\text { Texture }\end{array}$} \\
\hline & $\mathbf{N}$ & $\mathbf{P}$ & $\mathbf{K}$ & $\mathbf{F e}$ & $\mathbf{Z n}$ & Mn & $\mathbf{C u}$ & Sand & Silt & Clay & \\
\hline $0-30 \mathrm{~cm}$ & 55 & 4 & 45 & 0.3 & 0.1 & 0.4 & 1.53 & 96.8 & 2.5 & 0.7 & Sand \\
\hline $30-60 \mathrm{~cm}$ & 12 & 5 & 30 & 0.3 & 0.1 & 0.2 & 1.00 & 95.6 & 2.9 & 1.5 & Sand \\
\hline
\end{tabular}

Table (3): Chemical analysis of the irrigation water.

\begin{tabular}{|c|c|c|c|c|c|c|c|c|c|c|}
\hline \multirow{2}{*}{$\mathbf{P H}$} & \multirow{2}{*}{$\begin{array}{c}\text { EC } \\
\mathbf{d S} / \mathbf{m}\end{array}$} & \multicolumn{4}{|c|}{ Cations (meq/I) } & \multicolumn{4}{|c|}{ Anions (meq/I) } & \multirow[b]{2}{*}{ SAR } \\
\hline & & $\mathrm{Ca}^{++}$ & $\mathbf{M g}^{++}$ & $\mathrm{Na}^{+}$ & $\mathbf{K}^{+}$ & $\mathrm{CO3}^{--}$ & $\mathrm{HCO3}^{-}$ & $\mathbf{C L}^{-}$ & $\mathrm{SO}^{--}$ & \\
\hline 7.76 & 0.54 & 1.7 & 1.6 & 2.0 & 0.1 & 0.0 & 0.8 & 3.6 & 1.0 & 1.6 \\
\hline
\end{tabular}

Two field practices were conducted in a split-plot design with four replicates in the two seasons. The vineyard was established in 2002, with vine spacing of 2 $\mathrm{m}$ within rows and $3 \mathrm{~m}$ between rows. The main factor was the three pruning times $\left(1^{\text {st }}\right.$ December $(\mathrm{P} 1), 15^{\text {th }}$ December (P15) and 30 ${ }^{\text {th }}$ December (P30)) carried during dormant season to ten canes per vine with 12 buds per cane. Four renewal spurs (2 nodes) were retained per vine, while the sub main factor was four mulching treatments with sheet cover sleeves air white plastic (WSCT), air yellow plastic (YSCT), soil white plastic (WSCS) and soil yellow plastic (YSCS) which were randomly arranged in the sub-plots. The control was the field (no mulch with pruning $20^{\text {th }}$ December).

Air and soil mulch application were applied 25 days after pruning time in all treatments in both seasons. Removal mulching was either all-at-once or in two stages to allow for vine acclimation (Bowen et al., 2004a). All removal was done 15 days before harvest, in all treatments. All soil sleeves were constructed of 75 $\mathrm{cm}$ wide, length the row, white and yellow polyethylene, high- density, thickness $0.120 \mathrm{~mm}$ and processor against ultra violet rays. All air sleeves covered vegetative growth; the sleeve enclosures were supported at the top by trellis catch wires and closed at the bottom around the vine cane.

The following treatments were applied:

1 - Pruning in $1^{\text {st }}$ Dec. + White Sheet Cover Trees (P1WSCT).

2 - Pruning in $15^{\text {th }}$ Dec. + White Sheet Cover Trees (P15WSCT).

3 - Pruning in $30^{\text {th }}$ Dec. + White Sheet Cover Trees (P30WSCT). 
4- Pruning in $1^{\text {st }}$ Dec. + Yellow Sheet Cover Trees (P1YSCT).

5- Pruning in $15^{\text {th }}$ Dec. + Yellow Sheet Cover Trees (P15YSCT).

6- Pruning in $30^{\text {th }}$ Dec. + Yellow Sheet Cover Trees (P30YSCT).

7- Pruning in $1^{\text {st }}$ Dec. + White Sheet Cover Soil (P1WSCS).

8- Pruning in $15^{\text {th }}$ Dec. + White Sheet Cover Soil (P15WSCS).

9- Pruning in $30^{\text {th }}$ Dec. + White Sheet Cover Soil (P30WSCS).

10- Pruning in $1^{\text {st }}$ Dec. + Yellow Sheet Cover Soil (P1YSCS).

11- Pruning in $15^{\text {th }}$ Dec. + Yellow Sheet Cover Soil (P15YSCS).

12- Pruning in $30^{\text {th }}$ Dec. + Yellow Sheet Cover Soil (P30YSCS).

13- Control (Field Treatment).

The following parameters were determined to evaluate the effects of different plastic sheet coverings and pruning times:

Picking season: The time of harvesting was on average (18-May to 17-June) in 2007 season and (15-May to 14June) in 2008 season according to the effect of treatments as represented in other paper. Harvesting was took place when the value of total soluble solids reached $15.5 \pm 1 \%$.

Yield:

Average yield per vine $(\mathrm{kg})$ was recorded by counting the clusters on each vine and mean weight of cluster, then multiply the number of clusters times mean weight $(\mathrm{Kg})$. Sample per each replicate was harvested and taken to laboratory to determine the physical and chemical properties of berries:

Physical fruit characters:

Berry diameter $(\mathbf{m m})$ : Diameter of average of 50 berries per each sample was determined and then mean berry diameter was recorded.

Weight of berry (gm): Average weight per berry was determined from a random sample of 50 berries.

Number of berries / cluster: Number of berries for 5 clusters per each vine was counted; average of berries number per clusters was calculated.

Cluster weight (gm): The clusters were counted per vine and weighed, and then average weight of cluster/treatment was calculated.

Number of cluster/vine: The clusters were counted per vine and then average number of cluster/ treatment was calculated.

Cluster length (cm): Average lengths of 20 clusters per treatment were recorded at time of harvest.

Cluster width (cm): Average widths of 20 clusters per treatment were recorded at time of harvest.

Clusters compactness: Number of berries per cluster was counted to determine clusters compactness using the following equation according to Winkler et al. (1974) and Ali et al. (2000).
Clusters compactness ratio $=\frac{\text { No. of berries } / \text { cluster }}{\text { Cluster length }(\mathrm{cm})}$

Chemical fruit characters:

When the clusters attained $14-16 \%$ soluble solids content in berries, berry juice was extracted and filtered through two layers of cheese cloth to determine the effects of time pruning and air or soil cover sleeves on:

Total soluble solids (T.S.S \%): Total soluble solids (T.S.S \%) was determined using a hand refractometer.

Titratable acidity (\%): Total acid content of juice was determined by titrating $10 \mathrm{ml}$ juice sample against $\mathrm{NaOH}(0.1 \mathrm{~N})$. Acidity percentage was expressed as $\mathrm{mg}$ tartaric acid/100 ml juice according to A.O.A.C. (1980).

Activated acidity (pH value): Determined using a $\mathrm{pH}$ meter according to Diab (1968).

Vitamin C: Determined as ascorbic acid in juice berries by titration method using 2,6 Dichlorophenolindophenol dye and expressed as $\mathrm{mg} / 100 \mathrm{ml}$ juice (Bessey and King, 1933).

Total sugars: Total sugars were determined calorimetrically, using phenol and sulphuric acid according to the method of Malik and Singh (1980).

Reducing sugars: The reducing sugars were determined by the Nelson arsenate-molybdate colorimetric method (Dubois et al., 1956).

Non-reducing sugars: Calculated by difference according to the following equation:

$\%$ Non-reducing sugars $=\%$ total sugar $-\%$ total reducing sugars.

All the data collected were subjected to statistical analysis of variance as described by Gomez and Gomez (1984). The treatment means were compared using L.S.D. test at 0.05 level of probability.

\section{RESULTS AND DISCUSSION}

Yield:

Data illustrated in Tables (4 to 7) show effects of different pruning times, different plastic sheet coverings and their interaction on the yield of table grape "cv. Superior" in 2007 and 2008 seasons. No significant differences were found between the control and (P30) treatments which gave the highest value of yield $(\mathrm{Kg} / \mathrm{vine})$ in both seasons compared with all treatments. Moreover, the (P1) and (P15) treatments significantly decreased yield during the two seasons compared with control treatment. Different plastic sheet coverings during the two season revealed that, the (WSCT), (YSCT), (WSCS) and (YSCS) treatments caused a significant reduction in yield compared with the control treatment which gave the highest value of yield per vine $(\mathrm{Kg} / \mathrm{vine})$. Moreover, no significant differences were found among (WSCT) and (YSCT) which gave the lowest value of yield ( $\mathrm{Kg} / \mathrm{vine})$ in both seasons. The data concerning interaction effects of different plastic sheet coverings and pruning times on yield, revealed the highest yield (kg/vine) for vines treated with (P30YSCS) and (P30WSCS) as compared with control treatment. The differences were not big enough to be significant between (P15YSCS), (P15WSCS), 
(P30WSCT) and control in both seasons except (P15WSCT) treatment which cause a significant decrease in the first season compared by control. The treatments (P30YSCT), (P15WSCT), (P15YSCT), (P1YSCS), (P1WSCS), (P1WSCT) and (P1YSCT) significantly decreased yield as compared with control during the two experimental studies. The present findings are in line with those of Bowen et al. (2004b) who reported that sleeves (on trees) reduced yield. Also Phadung et al. (2005) who worked on 'Perlette' grape, results showed that plastic mulching (on soil) increased yield. The results were in disagreement with Novello et al. (2000) who showed that yield per vine increased under low density polyethylene + ethylvinyl acetate (LDPE+EVA). Furthermore, Rodriguez-Lovelle et al. (2000) showed that grape yields were lower with grass cover. Moreover, Shrestha et al. (2000) worked on 'Beauty Seedless' grape, found that the vines which growing under plastic roof from pruning to colour stage produced high yield and profit during both dry and rainy seasons.

\section{Physical fruit characters:}

The effects of different pruning times, plastic sheet coverings and their interaction on some physical fruit characters of table grape "cv. Superior" during both seasons is shown in Tables (4 to 10).

\section{Berry diameter:}

As for the effects of different pruning times on berry diameter in table grape "cv. Superior" during the two experimental studied, the control treatment gave the lowest value of berry diameter at the first and second seasons compared by all treatments. Furthermore, no significant differences were found between the (P1), (P15) and (P30) treatments which gave the highest value of berry diameter in both seasons compared to the control. Concerning the effects of different plastic sheet coverings on the berry diameter a significant increase was obtained by (YSCT) and (WSCT) treatments compared to control treatment in 2007 and 2008 seasons. Moreover, the differences were not significant between the (WSCS), (YSCS) and control treatments in both seasons. These results disagreed with those previously found by Hifny et al. (1994), they reported that the polyethylene either black or clear increased the yield components more than unmatched plots. Our data agreed with those Shrestha et al. (2000) who worked on 'Beauty Seedless' grape and showed that the vines growing under plastic roof from pruning to colour change stage produced high berry size.

\section{Berry weight:}

The (P1), (P15) and (P30) treatments increased berry weight significantly in both experimental seasons compared to control treatment which gave the lowest value. Also, a significant increase of berry weight was obtained by (YSCT), (WSCT), (YSCS) and (WSCS) treatments during the two experimental seasons compared with control treatment which gave the lowest value of berry weight. The (P30YSCT) treatment gave the highest berry weight in both seasons. Similar findings were reported by Shrestha et al. (2000) who worked on 'Beauty Seedless' grape they showed that the vines growing under plastic roof from pruning to colour change stage produced high berry weight.

\section{Number of berries /cluster:}

The control treatment gave the highest value of number of berries /cluster in both seasons compared by all treatments. Furthermore, the (P1), (P15) and (P30) treatments significantly decreased of barriers/cluster in both seasons compared with the control treatment except (P30) treatment in the second season which was similar with control treatment. A significant reduction in was caused by (YSCT), (WSCT), (YSCS) and (WSCS) treatments compared with control treatment which gave the highest number of berries /cluster. Moreover, the differences were not big enough to be significant among the (WSCT) and (YSCT) treatments which gave the lowest value in both seasons. No significant differences were found between the (P30YSCS), (P30WSCS), (P15YSCS), (P15WSCS) and control treatments during the two seasons, which gave the highest value in the first season but in the second season the treatments (P30YSCS), (P30WSCS) and (P15WSCS) gave the highest value. These results are in line with those found by Bowen et al. (2004b) who showed that sleeves reduced yield at one site due to lower cluster weights and apparently fewer berries per cluster.

\section{Cluster weight:}

Results showed that, the (P30) treatment gave the highest value of cluster weight in both seasons compared with all treatments. Also, the (P1) and (P15) treatments caused a significant increase in both seasons compared with control treatment which gave the lowest value. The (YSCT) and (WSCT) treatments gave the highest cluster weight in both seasons compared with all treatments. Also a significant increased caused by the (YSCS) and (WSCS) treatments during the two seasons compared with control treatment which gave the lowest value of cluster weight. Also, the treatment (P30YSCT) gave the highest cluster weight in the first season. It can be concluded from the above data that, all treatments increased significantly cluster weight during the two seasons compared with control treatment which gave the lowest value but in the second season the treatments (P1WSCS) and (P1YSCS) were similar to control treatment. This finding might gain support from the work previously done by Novello et al. (2000), Shrestha et al. (2000) and Phadung et al. (2005) who showed that plastic mulching increased fruit weight more than no mulching but fruit cluster weight was not affected by mulching treatments.

\section{Number of cluster/vine:}

The control treatment gave the highest value of cluster number/vine compared with all treatments in 2007 and 2008 seasons. Moreover, the (P1), (P15) and (P30) treatments resulted in a significant reduction in number of cluster /vine in both seasons compared with control treatment. Also, data showed that, the (YSCT), (WSCT), (YSCS) and (WSCS) treatments caused a significant reduction compared with control treatment which gave the highest number of cluster/vine at the first and second seasons. No significant differences were found for number of cluster/vine between 
(P30YSCS), (P30WSCS) and the control treatments which gave the highest value in both seasons, the other treatments significantly decreased number of cluster/vine during 2007 and 2008 seasons compared with control. The vines which growing under plastic roof from pruning to colour change stage of 'Beauty Seedless' grape produced high number of clusters during both dry and rainy seasons (Shrestha et al., 2000) our results disagreed with them. Also at one site the number of clusters per vine was unaffected by the treatments (Bowen et al., 2004a and b).

\section{Cluster length:}

The (P30) treatment gave the highest value of cluster length in both seasons compared in all treatments. Also, the (P15) treatment advanced significantly the cluster length in 2007 and 2008 seasons compared with control treatment. No significant differences were found between (YSCS), (WSCS) and control treatments which gave the lowest cluster length compared with all treatment in 2007 and 2008 seasons. The highest cluster length caused by (P30YSCT) treatment as compared with all treatments at the first and second seasons, but the (P1YSCS) and (P1WSCS) treatments produced the lowest values at the first season without significant differences between them.

\section{Cluster width:}

In conclusion, (P30YSCT) and (P30WSCT) treatments caused the highest values of cluster width as compared with control during the two seasons, but the treatments (P1YSCS) and (P1WSCS) caused the lowest values in both seasons.

\section{Cluster compactness:}

The (P30), (P15) and (P1) treatments decreased significantly the cluster compactness compared with control treatment which gave the highest value in the first and second seasons. The (YSCT) and (WSCT) treatments gave the lowest cluster compactness in 2007 and 2008 seasons compared with control treatment. No significant differences were found between the treatments (P1YSCS), (P1WSCS), (P15YSCS), (P15WSCS), (P30WSCS), (P30YSCS) and the control treatment which gave the highest value in the two seasons except the treatment (P30YSCS) in the first season.

\section{Chemicals fruit characters:}

Tables (11 to 14) illustrate the effects of different pruning times, plastic sheet coverings and their interaction on some chemical fruit characters in table grape "cv. Superior" in 2007 and 2008 seasons.

\section{Total soluble solid (T.S.S \%):}

It was noticed that T.S.S significantly increased by (P1) and (P15) treatments in comparison with that of control treatment in both seasons. Moreover, no significant differences were found between (P30) and control treatments in both seasons. No significant differences were found between the (WSCS), (YSCS) and control treatment which gave the lowest value of T.S.S. \%. Furthermore, the (YSCT) and (WSCT) treatments caused a significant increase in 2007 and 2008 seasons compared with control treatment.
However, it can be concluded that the treatments (P1WSCT), (P1YSCT), (P15WSCT), (P15YSCT), (P30WSCT) and (P30YSCT) affected T.S.S \% in the two seasons, meanwhile treatments (P15WSCS) and (P15YSCS) did not affect T.S.S \% in both seasons. The treatments (P30WSCS) and (P30YSCS) decreased T.S.S \% in both seasons. Concerning the present results, it appears that they are parallel to the finding of Shrestha et al. (2000), El-Shamma and Hassan (2001) and Phadung et al. (2005).

\section{Titratable Acidity (TA \%):}

Significant TA\% reduction was noticed with the (P1) and (P15) treatments compared with control treatment in both seasons except the (P15) treatment in first season which was similar to control treatment. It can be observed that treatment (P1) gave the lowest value of TA \% in both seasons. The (WSCS), (YSCS) and control treatments gave the highest value of TA \% during the two seasons compared with all treatments. Moreover, the fruit juice acidity percentages significantly decreased by the (WSCT) and (YSCT) treatments as compared with control treatment in 2007 and 2008 seasons. Significant reduction was noticed by the treatments (P1YSCT), (P1WSCT), (P1YSCS) and (P1WSCS) as compared with control during the two seasons. Also the (P30WSCT), (P30YSCT), (P15WSCT) and (P15YSCT) treatments significantly decreased fruit juice acidity percentages as compared with control in the second season but it was not affected in the first season. Concerning treatments (P15YSCS) and (P15WSCS), data showed no significant differences between these treatments and control treatment. The present findings are in agreement with those of Rodriguez-Lovelle et al. (2000), Shrestha et al. (2000) and Bowen et al. (2004a and b).

\section{Activated acidity (pH value):}

No significant differences were found between The (WSCS), (YSCS) and control treatment in the first and second seasons which gave the lowest $\mathrm{PH}$ value compared with all treatments. Also, all treatments caused a significant increase in $\mathrm{PH}$ as compared with control in the two experimental seasons, except the treatments (P15YSCS), (P15WSCS) and (P30YSCS) without significant differences between them and the control during 2007 and 2008 seasons.

\section{Vitamin C:}

Data showed that the (P1), (P15) and (P30) treatments advanced significantly the milligram vitamin $\mathrm{C}$ per $100 \mathrm{ml}$. juice in both seasons compared with control treatment except the treatment (P30) in the first season which was similar to control treatment. The (YSCT), (WSCT), (YSCS) and (WSCS) treatments advanced significantly the milligram vitamin $C$ per 100 $\mathrm{ml}$. juice as compared with control treatment during the two seasons, except the (YSCS) and (WSCS) treatments which were similar to control treatment in the first season. Also, the treatments (P1YSCT), (P1WSCT), (P15YSCT), (P15WSCT), (P30YSCT) and (P30WSCT) caused a significant increase in fruit vitamin $\mathrm{C}$ in both seasons as compared with control treatment. 
Total sugars:

Results showed that, the (P1), (P15) and (P30) treatments advanced significantly total sugars compared with control treatment in both seasons except the (P30) treatment in the first season which was similar to control treatment.Moreover, the (WSCT) and (YSCT) treatments gave the highest total sugars percentages as compared with control treatment during both seasons. On the other hand, no significant differences were found between The (WSCS), (YSCS) and control treatments which gave the lowest value compared with all treatments in 2007 and 2008 seasons. Result of both seasons generally indicated that, all treatments significantly increased total sugars percentage as compared with the control vines, except treatments (P15YSCS), (P15WSCS), (P30YSCS) and (P30WSCS). Treatments (P15YSCS) and (P15WSCS) did not affect total sugars percentage. Furthermore, treatments (P30YSCS) and (P30WSCS) decreased significantly total sugars percentage during 2008 season only. Such results are in line with those of Rodriguez-Lovelle et al. (2000) and El-Shamma and Hassan (2001) on grape and they found that the highest fruit quality (sugars) was obtained with black polyethylene mulch.

\section{Reducing sugars:}

Reducing sugars percentage decreased significantly by the $(\mathrm{P} 1),(\mathrm{P} 15)$ and $(\mathrm{P} 30)$ treatments compared to control treatment which gave the highest value in both seasons. Results also showed that, the differences were not big enough to be significant among the treatments
(WSCS), (YSCS) and control treatments which gave the highest value of reducing sugars percentage compared with all treatments during 2007 and 2008 seasons. On the other hand, the lowest reducing sugars percentages resulted from the (WSCT) and (YSCT) treatments in the first and second seasons. The treatments (P1YSCS) and (P1WSCS) gave the highest values of reducing sugars during 2007 and 2008 seasons as compared with control treatment. On the other hand, the highest accumulation temperatures may be caused by decreasing reducing sugars by the treatments (P1YSCT), (P1WSCT), (P15YSCT), (P15WSCT), (P30YSCT) and (P30WSCT) in both seasons as compared with control treatment.

\section{Non-reducing sugars:}

Significant increase in non- reducing sugars percentage was noticed by the (P1), (P15) and (P30) treatments in 2007 and 2008 seasons compared with control treatment which gave the lowest value. The data also indicated that the (WSCT) and (YSCT) treatments caused a significant increase in non- reducing sugars percentages compared with control treatment in the first and second seasons. Also it can be noticed that the treatment (YSCT) gave the highest value of nonreducing sugars percentages compared with all treatments in 2007 and 2008 seasons. The treatments (P1YSCT), (P1WSCT), (P15YSCT), (P15WSCT), (P30YSCT) and (P30WSCT) increased non- reducing sugars in the first and second seasons as compared with control treatment. That result may be caused by the highest accumulation temperatures degree.

Table (4): Effects of different pruning times on some physical fruit characters of table grape "cv. Superior" in 2007 and 2008 seasons.

\begin{tabular}{|c|c|c|c|c|c|c|c|c|c|c|c|c|}
\hline \multirow{2}{*}{$\begin{array}{l}\text { Pruning } \\
\text { time }\end{array}$} & \multicolumn{2}{|c|}{$\begin{array}{c}\text { Berry } \\
\text { diameter } \\
(\mathbf{m m})\end{array}$} & \multicolumn{2}{|c|}{$\begin{array}{c}\text { Berry } \\
\text { weight } \\
\text { (gm) }\end{array}$} & \multicolumn{2}{|c|}{$\begin{array}{c}\text { Number of } \\
\text { berries/cluster }\end{array}$} & \multicolumn{2}{|c|}{$\begin{array}{c}\text { Cluster weight } \\
\text { (gm) }\end{array}$} & \multicolumn{2}{|c|}{$\begin{array}{l}\text { Number of } \\
\text { cluster/vine }\end{array}$} & \multicolumn{2}{|c|}{$\begin{array}{l}\text { Yield/vine } \\
\text { (kg) }\end{array}$} \\
\hline & 2007 & 2008 & 2007 & 2008 & 2007 & 2008 & 2007 & 2008 & 2007 & 2008 & 2007 & 2008 \\
\hline $\begin{array}{c}1^{\text {st }} \\
\text { December }\end{array}$ & 19.13 & 19.57 & 4.16 & 4.39 & 113.31 & 116.11 & 471.67 & 510.14 & 8.94 & 10.56 & 4.22 & 5.39 \\
\hline $\begin{array}{c}15^{\text {th }} \\
\text { December }\end{array}$ & 18.91 & 19.56 & 4.09 & 4.39 & 125.94 & 129.50 & 515.43 & 569.02 & 18.38 & 20.63 & 9.47 & 11.74 \\
\hline $\begin{array}{c}30^{\text {th }} \\
\text { December }\end{array}$ & 19.25 & 19.99 & 4.25 & 4.58 & 128.00 & 131.01 & 544.00 & 599.33 & 22.63 & 24.56 & 12.31 & 14.72 \\
\hline Control & 17.65 & 18.00 & 3.20 & 3.65 & 130.30 & 131.51 & 416.96 & 479.98 & 27.75 & 30.25 & 11.57 & 14.52 \\
\hline $\begin{array}{l}\text { L.S.D at } \\
0.05 \%\end{array}$ & 0.37 & 0.89 & 0.14 & 0.15 & 1.04 & 0.95 & 22.62 & 22.24 & 0.69 & 1.02 & 0.95 & 0.49 \\
\hline
\end{tabular}


Table (5): Effects of different plastic sheet coverings on some physical fruit characters of table grape "cv. Superior" in 2007 and 2008 seasons.

\begin{tabular}{|c|c|c|c|c|c|c|c|c|c|c|c|c|}
\hline \multirow{2}{*}{$\begin{array}{l}\text { Covering } \\
\text { Sheets }\end{array}$} & \multicolumn{2}{|c|}{$\begin{array}{c}\text { Berry } \\
\text { diameter } \\
(\mathbf{m m})\end{array}$} & \multicolumn{2}{|c|}{$\begin{array}{c}\text { Berry } \\
\text { weight } \\
\text { (gm) }\end{array}$} & \multicolumn{2}{|c|}{$\begin{array}{c}\text { Number of } \\
\text { berries/cluster }\end{array}$} & \multicolumn{2}{|c|}{$\begin{array}{c}\text { Cluster weight } \\
\text { (gm) }\end{array}$} & \multicolumn{2}{|c|}{$\begin{array}{l}\text { Number of } \\
\text { cluster/vine }\end{array}$} & \multicolumn{2}{|c|}{$\begin{array}{l}\text { Yield/vine } \\
\text { (kg) }\end{array}$} \\
\hline & 2007 & 2008 & 2007 & 2008 & 2007 & 2008 & 2007 & 2008 & 2007 & 2008 & 2007 & 2008 \\
\hline WSCT & 20.00 & 20.46 & 4.34 & 4.63 & 119.71 & 123.31 & 519.73 & 571.25 & 13.25 & 15.17 & 6.89 & 8.67 \\
\hline YSCT & 20.54 & 21.13 & 4.60 & 4.84 & 119.70 & 123.30 & 550.62 & 597.02 & 12.00 & 13.75 & 6.61 & 8.21 \\
\hline WSCS & 18.00 & 18.63 & 3.83 & 4.13 & 125.12 & 127.71 & 478.50 & 526.76 & 20.58 & 22.42 & 9.85 & 11.81 \\
\hline YSCS & 17.83 & 18.61 & 3.91 & 4.22 & 125.11 & 127.81 & 488.89 & 538.93 & 20.75 & 23.00 & 10.14 & 12.40 \\
\hline Control & 17.65 & 18.00 & 3.20 & 3.65 & 130.32 & 131.51 & 416.96 & 479.98 & 27.75 & 30.25 & 11.57 & 14.52 \\
\hline $\begin{array}{l}\text { L.S.D at } \\
0.05 \%\end{array}$ & 0.65 & 0.82 & 0.23 & 0.22 & 1.38 & 1.99 & 32.81 & 29.04 & 0.76 & 1.20 & 0.83 & 0.97 \\
\hline
\end{tabular}

Table (6): Interaction effects of different plastic sheet coverings and pruning times on some physical fruit characters of table grape "cv. Superior" in 2007 season.

\begin{tabular}{|c|c|c|c|c|c|c|c|}
\hline \multicolumn{2}{|c|}{ Treatments } & \multirow{2}{*}{$\begin{array}{c}\text { Berry } \\
\text { diameter } \\
(\mathrm{mm})\end{array}$} & \multirow{2}{*}{$\begin{array}{c}\text { Berry } \\
\text { weight } \\
\text { (gm) }\end{array}$} & \multirow[b]{2}{*}{$\begin{array}{c}\text { Number of } \\
\text { berries/cluster }\end{array}$} & \multirow{2}{*}{$\begin{array}{c}\text { Cluster } \\
\text { weight } \\
\text { (gm) }\end{array}$} & \multirow{2}{*}{$\begin{array}{l}\text { Number of } \\
\text { cluster/vine }\end{array}$} & \multirow{2}{*}{$\begin{array}{l}\text { Yield/vine } \\
\quad(\mathrm{kg})\end{array}$} \\
\hline $\begin{array}{c}\text { Pruning } \\
\text { time }\end{array}$ & $\begin{array}{c}\text { Covering } \\
\text { Sheets }\end{array}$ & & & & & & \\
\hline \multirow{4}{*}{$\begin{array}{c}1^{\text {st }} \\
\text { December }\end{array}$} & WSCT & 20.00 & 4.42 & 112.01 & 495.61 & 8.00 & 3.97 \\
\hline & YSCT & 20.50 & 4.42 & 112.02 & 495.61 & 7.00 & 3.47 \\
\hline & WSCS & 18.00 & 3.90 & 114.80 & 447.72 & 10.25 & 4.59 \\
\hline & YSCS & 18.00 & 3.90 & 114.31 & 445.77 & 10.50 & 4.68 \\
\hline \multirow{4}{*}{$\begin{array}{c}15^{\text {th }} \\
\text { December }\end{array}$} & WSCT & 19.50 & 4.10 & 122.80 & 503.48 & 14.50 & 7.30 \\
\hline & YSCT & 20.13 & 4.50 & 122.30 & 550.35 & 13.25 & 7.29 \\
\hline & WSCS & 18.00 & 3.80 & 129.33 & 491.34 & 22.75 & 11.18 \\
\hline & YSCS & 18.00 & 3.98 & 129.51 & 514.76 & 23.00 & 11.84 \\
\hline \multirow{4}{*}{$\begin{array}{c}3^{\text {th }} \\
\text { December }\end{array}$} & WSCT & 20.50 & 4.50 & 124.30 & 559.35 & 17.25 & 9.65 \\
\hline & YSCT & 21.00 & 4.88 & 124.81 & 608.43 & 15.75 & 9.58 \\
\hline & WSCS & 18.00 & 3.78 & 131.31 & 495.66 & 28.75 & 14.25 \\
\hline & YSCS & 17.50 & 3.85 & 131.50 & 506.28 & 28.75 & 14.56 \\
\hline Control & & 17.65 & 3.20 & 130.31 & 416.96 & 27.75 & 11.57 \\
\hline \multicolumn{2}{|c|}{ L.S.D at $0.05 \%$} & 1.13 & 0.40 & 2.39 & 56.83 & 1.31 & 1.43 \\
\hline
\end{tabular}


Table (7): Interaction effects of different plastic sheet coverings and pruning time on some physical fruit characters of table grape "cv. Superior" in 2008 season.

\begin{tabular}{|c|c|c|c|c|c|c|c|}
\hline \multicolumn{2}{|c|}{ Treatments } & \multirow{2}{*}{$\begin{array}{c}\text { Berry } \\
\text { diameter } \\
(\mathbf{m m})\end{array}$} & \multirow{2}{*}{$\begin{array}{c}\text { Berry } \\
\text { weight } \\
\text { (gm) }\end{array}$} & \multirow{2}{*}{$\begin{array}{c}\text { Number of } \\
\text { berries/cluster }\end{array}$} & \multirow{2}{*}{$\begin{array}{c}\text { Cluster } \\
\text { weight } \\
\text { (gm) }\end{array}$} & \multirow{2}{*}{$\begin{array}{l}\text { Number of } \\
\text { cluster/vine }\end{array}$} & \multirow{2}{*}{$\begin{array}{c}\text { Yield/vine } \\
\text { (kg) }\end{array}$} \\
\hline Pruning time & $\begin{array}{c}\text { Covering } \\
\text { Sheets }\end{array}$ & & & & & & \\
\hline \multirow{5}{*}{$\begin{array}{c}1^{\text {st }} \\
\text { December }\end{array}$} & WSCT & 20.38 & 4.58 & 115.07 & 526.13 & 9.25 & 4.87 \\
\hline & YSCT & 20.88 & 4.73 & 115.09 & 543.38 & 8.50 & 4.62 \\
\hline & WSCS & 18.50 & 4.15 & 117.31 & 486.80 & 12.25 & 5.96 \\
\hline & YSCS & 18.50 & 4.13 & 116.81 & 481.80 & 12.25 & 5.90 \\
\hline & WSCT & 20.00 & 4.48 & 126.50 & 566.09 & 16.00 & 9.06 \\
\hline \multirow{3}{*}{$\begin{array}{c}15^{\text {th }} \\
\text { December }\end{array}$} & YSCT & 21.00 & 4.78 & 126.33 & 603.08 & 14.75 & 8.90 \\
\hline & WSCS & 18.50 & 4.03 & 132.31 & 532.51 & 25.25 & 13.45 \\
\hline & YSCS & 18.73 & 4.30 & 133.00 & 571.91 & 26.50 & 15.16 \\
\hline \multirow{4}{*}{$\begin{array}{c}30^{\text {th }} \\
\text { December }\end{array}$} & WSCT & 21.00 & 4.85 & 128.33 & 622.26 & 20.25 & 12.60 \\
\hline & YSCT & 21.50 & 5.03 & 128.83 & 647.22 & 18.00 & 11.65 \\
\hline & WSCS & 18.88 & 4.20 & 133.51 & 560.07 & 29.75 & 16.66 \\
\hline & YSCS & 18.60 & 4.23 & 133.50 & 564.04 & 30.25 & 17.06 \\
\hline Control & & 18.00 & 3.65 & 131.51 & 479.98 & 30.25 & 14.52 \\
\hline \multicolumn{2}{|c|}{ L.S.D at $0.05 \%$} & 1.42 & 0.38 & 3.44 & 50.30 & 2.074 & 1.69 \\
\hline
\end{tabular}

Table (8): Effects of different pruning times on some cluster characters of table grape "cv. Superior" in 2007 and 2008 seasons.

\begin{tabular}{|c|c|c|c|c|c|c|}
\hline \multirow[t]{2}{*}{ Pruning time } & \multicolumn{2}{|c|}{$\begin{array}{c}\text { Cluster length } \\
\text { (cm) }\end{array}$} & \multicolumn{2}{|c|}{$\begin{array}{l}\text { Cluster width } \\
\text { (cm) }\end{array}$} & \multicolumn{2}{|c|}{$\begin{array}{c}\begin{array}{c}\text { Cluster } \\
\text { Compactness }\end{array} \\
\end{array}$} \\
\hline & 2007 & 2008 & 2007 & 2008 & 2007 & 2008 \\
\hline $\begin{array}{c}1^{\text {st }} \\
\text { December }\end{array}$ & 16.33 & 16.83 & 12.58 & 12.86 & 6.94 & 6.90 \\
\hline $\begin{array}{c}15^{\text {th }} \\
\text { December }\end{array}$ & 18.59 & 19.41 & 13.44 & 15.01 & 6.77 & 6.67 \\
\hline $\begin{array}{c}30^{\text {th }} \\
\text { December }\end{array}$ & 19.28 & 20.18 & 14.53 & 15.75 & 6.64 & 6.49 \\
\hline Control & 17.77 & 18.25 & 13.52 & 13.80 & 7.33 & 7.21 \\
\hline L.S.D at $0.05 \%$ & 0.44 & 0.55 & 0.16 & 0.28 & 0.14 & 0.21 \\
\hline
\end{tabular}


Table (9): Effects of different plastic sheet coverings on some cluster characters of table grape "cv. Superior" in 2007 and 2008 seasons.

\begin{tabular}{cccccccc}
\hline \multirow{2}{*}{$\begin{array}{c}\text { Covering } \\
\text { Sheets }\end{array}$} & \multicolumn{2}{c}{$\begin{array}{c}\text { Cluster length } \\
\text { (cm) }\end{array}$} & \multicolumn{2}{c}{$\begin{array}{c}\text { Cluster width } \\
\text { (cm) }\end{array}$} & \multicolumn{2}{c}{$\begin{array}{c}\text { Cluster } \\
\text { Compactness }\end{array}$} \\
\cline { 2 - 7 } WSCT & $\mathbf{2 0 0 7}$ & $\mathbf{2 0 0 8}$ & $\mathbf{2 0 0 7}$ & $\mathbf{2 0 0 8}$ & $\mathbf{2 0 0 7}$ & $\mathbf{2 0 0 8}$ \\
YSCT & 18.46 & 19.50 & 13.98 & 14.92 & 6.48 & 6.32 \\
WSCS & 17.78 & 20.08 & 14.09 & 15.27 & 6.37 & 6.14 \\
YSCS & 17.44 & 17.76 & 12.91 & 13.80 & 7.17 & 7.19 \\
Control & 17.58 & 17.89 & 13.08 & 14.18 & 7.12 & 7.14 \\
L.S.D at 0.05\% & 0.46 & 18.25 & 13.52 & 13.80 & 7.33 & 7.21 \\
\hline
\end{tabular}

Table (10): Interaction effects of different plastic sheet coverings and pruning times on some cluster characters of table grape "cv. Superior" in 2007 and 2008 seasons.

\begin{tabular}{|c|c|c|c|c|c|c|c|}
\hline \multicolumn{2}{|c|}{ Treatments } & \multicolumn{2}{|c|}{$\begin{array}{l}\text { Cluster length } \\
\text { (cm) }\end{array}$} & \multicolumn{2}{|c|}{$\begin{array}{l}\text { Cluster width } \\
\text { (cm) }\end{array}$} & \multicolumn{2}{|c|}{$\begin{array}{c}\text { Cluster } \\
\text { compactness }\end{array}$} \\
\hline Pruning time & $\begin{array}{l}\text { Covering } \\
\text { Sheets }\end{array}$ & 2007 & 2008 & 2007 & 2008 & 2007 & 2008 \\
\hline \multirow{4}{*}{$\begin{array}{c}1^{\text {st }} \\
\text { December }\end{array}$} & WSCT & 16.80 & 17.50 & 13.05 & 13.50 & 6.67 & 6.57 \\
\hline & YSCT & 16.98 & 17.70 & 13.05 & 13.50 & 6.60 & 6.50 \\
\hline & WSCS & 15.73 & 16.00 & 12.07 & 12.05 & 7.30 & 7.33 \\
\hline & YSCS & 15.82 & 16.13 & 12.13 & 12.40 & 7.23 & 7.24 \\
\hline \multirow{5}{*}{$\begin{array}{c}15^{\text {th }} \\
\text { December }\end{array}$} & WSCT & 19.08 & 20.00 & 14.05 & 14.75 & 6.44 & 6.33 \\
\hline & YSCT & 19.20 & 20.50 & 13.82 & 15.25 & 6.37 & 6.16 \\
\hline & WSCS & 18.00 & 18.52 & 12.88 & 14.85 & 7.18 & 7.14 \\
\hline & YSCS & 18.08 & 18.63 & 13.00 & 15.20 & 7.16 & 7.14 \\
\hline & WSCT & 19.50 & 21.00 & 14.82 & 16.50 & 6.37 & 6.11 \\
\hline \multirow{3}{*}{$\begin{array}{c}30^{\text {th }} \\
\text { December }\end{array}$} & YSCT & 20.17 & 22.05 & 15.40 & 17.05 & 6.19 & 5.84 \\
\hline & WSCS & 18.60 & 18.75 & 13.77 & 14.50 & 7.06 & 7.12 \\
\hline & YSCS & 18.85 & 18.92 & 14.13 & 14.95 & 6.98 & 7.06 \\
\hline Control & & 17.77 & 18.25 & 13.52 & 13.80 & 7.33 & 7.21 \\
\hline L.S.D at $0.05 \%$ & & 0.80 & 1.39 & 1.05 & 0.71 & 0.28 & 0.48 \\
\hline
\end{tabular}


Table (11): Effects of different pruning times on some chemical fruit characters of table grape "cv. Superior" on 2007 and 2008 seasons.

\begin{tabular}{|c|c|c|c|c|c|c|c|c|c|c|c|c|c|c|}
\hline \multirow{2}{*}{ Pruning time } & \multicolumn{2}{|c|}{$\begin{array}{c}\text { T.S.S } \\
(\%)\end{array}$} & \multicolumn{2}{|c|}{$\begin{array}{l}\text { T.A } \\
(\%)\end{array}$} & \multicolumn{2}{|c|}{ PH } & \multicolumn{2}{|c|}{$\begin{array}{c}\text { Vitamin C } \\
\text { (mg/100 } \\
\text { ml juice) }\end{array}$} & \multicolumn{2}{|c|}{$\begin{array}{c}\text { Total sugar } \\
(\%)\end{array}$} & \multicolumn{2}{|c|}{$\begin{array}{l}\text { Reducing } \\
\text { sugar } \\
(\%)\end{array}$} & \multicolumn{2}{|c|}{$\begin{array}{l}\text { Non- } \\
\text { reducing } \\
\text { sugar } \\
(\%)\end{array}$} \\
\hline & 2007 & 2008 & 2007 & 2008 & 2007 & 2008 & 2007 & 2008 & 2007 & 2008 & 2007 & 2008 & 2007 & 2008 \\
\hline $15^{\text {th }}$ December & 15.63 & 15.50 & 0.39 & 0.42 & 4.43 & 4.24 & 3.31 & 3.31 & 13.95 & 13.83 & 8.21 & 8.05 & 5.74 & 5.78 \\
\hline $30^{\text {th }}$ December & 15.25 & 15.03 & 0.46 & 0.52 & 4.10 & 4.03 & 3.23 & 3.18 & 13.35 & 13.04 & 7.72 & 7.34 & 5.63 & 5.69 \\
\hline L.S.D at $0.05 \%$ & 0.20 & 0.16 & 0.07 & 0.03 & 0.12 & 0.28 & 0.35 & 0.09 & 0.38 & 0.23 & 0.40 & 0.32 & 0.28 & 0.29 \\
\hline
\end{tabular}

Table (12): Effects of different plastic sheet coverings on some chemical fruit characters of table grape "cv. Superior" in 2007 and 2008 seasons.

\begin{tabular}{|c|c|c|c|c|c|c|c|c|c|c|c|c|c|c|}
\hline \multirow[t]{2}{*}{$\begin{array}{l}\text { Covering } \\
\text { Sheets }\end{array}$} & \multicolumn{2}{|c|}{$\begin{array}{c}\text { T.S.S } \\
(\%)\end{array}$} & \multicolumn{2}{|c|}{$\begin{array}{l}\text { T.A } \\
(\%)\end{array}$} & \multicolumn{2}{|c|}{ PH } & \multicolumn{2}{|c|}{$\begin{array}{c}\text { Vitamin C } \\
\text { (mg/100 } \\
\text { ml juice) }\end{array}$} & \multicolumn{2}{|c|}{$\begin{array}{c}\text { Total sugar } \\
(\%)\end{array}$} & \multicolumn{2}{|c|}{$\begin{array}{c}\text { Reducing } \\
\text { sugar } \\
(\%)\end{array}$} & \multicolumn{2}{|c|}{$\begin{array}{l}\text { Non- } \\
\text { reducing } \\
\text { sugar } \\
(\%)\end{array}$} \\
\hline & 2007 & 2008 & 2007 & 2008 & 2007 & 2008 & 2007 & 2008 & 2007 & 2008 & 2007 & 2008 & 2007 & 2008 \\
\hline YSCT & 16.00 & 16.00 & 0.31 & 0.34 & 4.73 & 4.69 & 3.75 & 3.64 & 15.02 & 14.80 & 4.98 & 4.67 & 10.03 & 10.13 \\
\hline WSCS & 15.27 & 15.02 & 0.44 & 0.48 & 4.12 & 3.97 & 3.09 & 3.09 & 13.27 & 13.06 & 11.45 & 11.35 & 1.82 & 1.71 \\
\hline Control & 15.20 & 14.90 & 0.45 & 0.50 & 4.01 & 3.81 & 2.91 & 2.95 & 13.13 & 12.70 & 11.30 & 11.03 & 1.83 & 1.67 \\
\hline $\begin{array}{c}\text { L.S.D at } \\
0.05 \%\end{array}$ & 0.33 & 0.37 & 0.06 & 0.04 & 0.20 & 0.30 & 0.26 & 0.08 & 0.60 & 0.42 & 0.40 & 0.37 & 0.38 & 0.32 \\
\hline
\end{tabular}


Table (13): Interaction effects of different plastic sheet coverings and pruning times on some chemical fruit characters of table grape "cv. Superior" in 2007 season.

\begin{tabular}{|c|c|c|c|c|c|c|c|c|}
\hline \multicolumn{2}{|c|}{ Treatments } & \multirow{2}{*}{$\begin{array}{l}\text { T.S.S } \\
(\%)\end{array}$} & \multirow{2}{*}{$\begin{array}{l}\text { T.A } \\
\text { (\%) }\end{array}$} & \multirow{2}{*}{ PH } & \multirow{2}{*}{$\begin{array}{c}\text { Vitamin C } \\
\text { (mg/100 } \\
\text { ml juice) }\end{array}$} & \multirow{2}{*}{$\begin{array}{c}\text { Total } \\
\text { sugar } \\
(\%)\end{array}$} & \multirow{2}{*}{$\begin{array}{c}\text { Reducing } \\
\text { sugar } \\
(\%)\end{array}$} & \multirow{2}{*}{$\begin{array}{c}\text { Non- } \\
\text { reducing } \\
\text { sugar } \\
(\%)\end{array}$} \\
\hline $\begin{array}{c}\text { Pruning } \\
\text { time }\end{array}$ & $\begin{array}{c}\text { Covering } \\
\text { Sheets }\end{array}$ & & & & & & & \\
\hline \multirow{4}{*}{$\begin{array}{c}1^{\text {st }} \\
\text { December }\end{array}$} & WSCT & 16.00 & 0.25 & 4.75 & 3.70 & 15.03 & 5.26 & 9.77 \\
\hline & YSCT & 16.00 & 0.24 & 4.83 & 4.14 & 15.63 & 5.23 & 10.40 \\
\hline & WSCS & 16.00 & 0.33 & 4.65 & 3.26 & 14.57 & 12.58 & 1.99 \\
\hline & YSCS & 16.00 & 0.32 & 4.60 & 3.26 & 14.61 & 12.63 & 1.98 \\
\hline \multirow{5}{*}{$\begin{array}{c}15^{\text {th }} \\
\text { December }\end{array}$} & WSCT & 16.00 & 0.34 & 4.73 & 3.52 & 14.81 & 5.30 & 9.50 \\
\hline & YSCT & 16.00 & 0.34 & 4.78 & 3.60 & 14.80 & 4.92 & 9.88 \\
\hline & WSCS & 15.30 & 0.44 & 4.10 & 3.10 & 13.07 & 11.31 & 1.76 \\
\hline & YSCS & 15.20 & 0.45 & 4.13 & 3.02 & 13.11 & 11.31 & 1.80 \\
\hline & WSCT & 16.00 & 0.37 & 4.54 & 3.51 & 14.38 & 5.10 & 9.28 \\
\hline \multirow{3}{*}{$\begin{array}{c}\mathbf{3 0}^{\text {th }} \\
\text { December }\end{array}$} & YSCT & 16.00 & 0.34 & 4.60 & 3.51 & 14.62 & 4.80 & 9.82 \\
\hline & WSCS & 14.50 & 0.56 & 3.60 & 2.90 & 12.18 & 10.47 & 1.71 \\
\hline & YSCS & 14.50 & 0.58 & 3.65 & 3.01 & 12.21 & 10.51 & 1.70 \\
\hline \multicolumn{2}{|l|}{ Control } & 15.20 & 0.45 & 4.01 & 2.91 & 13.13 & 11.30 & 1.83 \\
\hline \multicolumn{2}{|c|}{ L.S.D at $0.05 \%$} & 0.58 & 0.10 & 0.35 & 0.45 & 1.03 & 0.70 & 0.66 \\
\hline
\end{tabular}


Table (14): Interaction effects of different plastic sheet coverings and pruning times on some chemical fruit characters of table grape "cv. Superior" in 2008 season.

\begin{tabular}{|c|c|c|c|c|c|c|c|c|}
\hline \multicolumn{2}{|c|}{ Treatments } & \multirow[b]{2}{*}{$\begin{array}{l}\text { T.S.S } \\
(\%)\end{array}$} & \multirow[b]{2}{*}{$\begin{array}{l}\text { T.A } \\
\text { (\%) }\end{array}$} & \multirow[b]{2}{*}{ PH } & \multirow{2}{*}{$\begin{array}{c}\text { Vitamin C } \\
\text { (mg/100 } \\
\text { ml juice) }\end{array}$} & \multirow{2}{*}{$\begin{array}{c}\text { Total } \\
\text { sugar } \\
(\%)\end{array}$} & \multirow{2}{*}{$\begin{array}{c}\text { Reducin } \\
\text { g sugar } \\
(\%)\end{array}$} & \multirow{2}{*}{$\begin{array}{l}\text { Non- } \\
\text { reducing } \\
\text { sugar } \\
(\%)\end{array}$} \\
\hline $\begin{array}{l}\text { Pruning } \\
\text { time }\end{array}$ & $\begin{array}{l}\text { Covering } \\
\text { Sheets }\end{array}$ & & & & & & & \\
\hline \multirow{5}{*}{$\begin{array}{c}1^{\text {st }} \\
\text { December }\end{array}$} & WSCT & 16.00 & 0.29 & 4.69 & 3.67 & 15.00 & 5.15 & 9.85 \\
\hline & YSCT & 16.00 & 0.27 & 4.81 & 3.92 & 15.30 & 4.80 & 10.50 \\
\hline & & & & & & & & \\
\hline & WSCS & 16.00 & 0.33 & 4.61 & 3.26 & 14.50 & 12.70 & 1.80 \\
\hline & YSCS & 16.00 & 0.33 & 4.60 & 3.27 & 14.50 & 12.68 & 1.82 \\
\hline \multirow{5}{*}{$\begin{array}{c}15^{\text {th }} \\
\text { December }\end{array}$} & WSCT & 16.00 & 0.36 & 4.60 & 3.50 & 14.60 & 4.92 & 9.68 \\
\hline & YSCT & 16.00 & 0.35 & 4.69 & 3.54 & 14.70 & 4.70 & 10.00 \\
\hline & WSCS & 15.00 & 0.48 & 3.80 & 3.11 & 13.00 & 11.30 & 1.70 \\
\hline & YSCS & 15.00 & 0.48 & 3.85 & 3.10 & 13.00 & 11.27 & 1.73 \\
\hline & WSCT & 16.00 & 0.40 & 4.53 & 3.44 & 14.30 & 4.70 & 9.60 \\
\hline \multirow{3}{*}{$\begin{array}{c}30^{\text {th }} \\
\text { December }\end{array}$} & YSCT & 16.00 & 0.40 & 4.57 & 3.47 & 14.40 & 4.51 & 9.89 \\
\hline & WSCS & 14.05 & 0.64 & 3.50 & 2.90 & 11.70 & 10.06 & 1.64 \\
\hline & YSCS & 14.07 & 0.63 & 3.51 & 2.91 & 11.74 & 10.10 & 1.64 \\
\hline \multicolumn{2}{|l|}{ Control } & 14.90 & 0.50 & 3.81 & 2.95 & 12.70 & 11.03 & 1.67 \\
\hline \multicolumn{2}{|c|}{ L.S.D at $0.05 \%$} & 0.63 & 0.06 & 0.51 & 0.14 & 0.72 & 0.63 & 0.55 \\
\hline
\end{tabular}

\section{REFERENCES}

A. O. A. C. (1980). "Association of Official of Analytical Chemist". $14^{\text {th }}$ ed. Published by the A. O. A. C.,P. O. Box 540, Washington, 4 D.C., USA.

Ali, M. A., M. M. EL-Mogy and I. Rizk (2000). Effect of cane length on bud behaviour, bunch characteristics, wood ripening and chemical contents of Thompson seedless grapevine. Agric. Sci., Mansoura Univ., 25(3): 1707.

Alxander, S. E. and G. H. Clough (1998). Spunbonded rowcovers and calcium fertilization improve quality and yield in bell pepper. HortScience, 33: 11501152.

Anonymous (2009). Grape Production in Australia http://www.fao.org/docrep/003/ x6897e/x6897e04.htm
Asker, H. M., M. K. Al-Jebori, M. N. Hamey and A. M. Al-Ani (1987). Effect of sulfur dioxide gas relative humidity on the storage capability of two cultivars of local grapes (Vitis vinifera). J. Agric. and Water Resources Res., Plant Production (Iraq) 6(3):75-90.

Bessy, O. A. and C. G. King (1933). The distribution of vitamin $\mathrm{C}$ in plant and animal tissues and its determination. J. Biol. Chem., 103,687.

Bowen, P. (1998). Growing Echinacea and other crops intensively. Proc. Lower Mainland Horticultural Improvement Assoc. 40th Annual Short Course. BC Ministry of Agriculture and Food, Abbotsford, BC. 23-25.

Bowen, P. A., C. P. Bogdanoff and B. Estergaard (2004a). Impacts of using polyethylene sleeves and wavelength-selective mulch in vineyards. I. Effects 
on air and soil temperatures and degree day accumulation. Can. J. Plant Sci., 84: 545-553.

Bowen, P. A., C. P. Bogdanoff and B. Estergaard (2004b). Impacts of using polyethylene sleeves and wavelength-selective mulch in vineyards. Effects on growth, leaf gas exchange, yield components and fruit quality in Vitis vinifera cv. Merlot. Can. J. Plant Sci., 84: 555-568.

Bowen, P. A. and B. M. Frey (2002). Response of plasticultured bell pepper to staking, irrigation frequency and fertigated nitrogen rate. HortScience, 37: 95-100.

Bowen, P. A. and W. M. Kliewer (1990). Influence of clonal variation, pruning severity and cane structure on yield component development in Cabernet Sauvignon grapevine. J. Am. Soc. HortScience, 115,530 .

Caldwell, M. M. (1970). Plants gas exchange at high wind speeds. Plant Physiol., 46: 535-537.

Diab, M. A. (1968) the chemical composition of Hibiscus sabdariffa, M.Sc. thesis Fac. Agric. Cairo Univ.

Dubois, M., K. A. Cilles, J. K. Hamiltion and P. A. Rober (1956). Colorimetric method for determination of sugar and related substances. Anal. Chem., 28: 350 -356.

El-Hammady, A. M. and N. Abdel Hamid (1995). The effect of vine bud load on yield and fruit quality of King Ruby grapevine. Annals Agric. Sci., Cairo, 40(1): 279 .

El-Shahat, S. S. (1992). Bud dormancy in Thompson Seedless grape as affect by some field practices. Ph.D. Thesis, Fac. Agric., Mansoura Univ.

El-Shamma, M. S. and A. A. A. Hassan (2001). A comparative study of some weed control methods on Thompson seedless vines. Assiut J. Agric. Sci., 32(1): 145-155.

Gaye, M. M., G. W. Eaton and P. A. Jolliffe (1992a). Row covers and plant architecture influence development and special distribution of bell pepper fruit. HortScience, 27: 397-399.

Gaye, M. M., P. A. Jolliffe and A. R. Maurer (1992b). Row covers and population density effects on yield of bell peppers south coastal British Columbia. Can. J. Plant Sci., 72: 901-909.

Gomez, K. A. and A. A. Gomez (1984). Statistical procedures for Agric. Res. $2^{\text {nd }}$ Ed. John Wiley sons. Inc-New York.

Heilman, J. L., K. J. McInnes, R. W. Gesch, R. J. Lascano and M. J. Savage (1996). Effects of trellising on the energy balance of a vineyard. Agric. For. Meteorol., 81(1/2): 79-93.

Hifny, H. A., G. A. Baghaday and M. S. Arafa (1994). Response of Growth and Yield of "Banaty" Grapevine to soil Mulch as a tool for Weed Control. Egypt. J. Hort., 21(1): 81-92.

Howell, G. S. and K. Strieglar (1998). Pruning grapevine in Michigan. Hort. Extension Bull., Michigan state Univ. Bull., 25,1.

Jenni, S., K. A. Stewart, D. C. Cloutier and G. Bourgeois (1998). Effect of polyethylene mulches, irrigation methods and row covers on soil and air temperature and yield of muskmelon. J. Amer. Soc. Hort. Sci., 33: 215-221.

Katerji, N., F. A. Daudet, A. Carbonneau and N. Ollat (1994). Etude à l'échelle de la planteentière du fonctionnement hydrique et phosynthétique de la vigne: comparaison des systèmes de conduitetra ditionnel et an Lyre. Vitis., 33: 197-203.

Kliewer, W. M. (1967). Annual cyclic changes in the concentration of sugars and organic acids in Thompson Seedless grapevine. J. Amer. Soc. Hort. Sci., 91, 205.

Liberman L. (2009). More Red globe seeded grapes go domestic market. http://www.fruitgrowersnews.com/pages/2002/issu e02_03/02_03_gra pes.html.

Malik, C. P. and M. B. Singh (1980). Plant enzymology and histoenzymology. A. text manul. Kalyani. Pub. New Delhi.

Naor, A., B. Bravdo and J. Gelobter (1994). Gasexchange and water relations in field-grown Sauvignon blanc grapevines. Am. J. Enol. Vitis., 45(4): 423-428.

Novello, V., L. Palma and L. Tarricone (1999). Influence of cane girdling and plastic covering on leaf gas exchange, water potential and viticultural performance of table grape cv. (Matilde). Vitis, 38: 51-54.

Novello, V., L. Palma, L. Tarricone and G. Vox (2000). Effects of different plastic sheet covering on microclimate and berry ripening of table grape cv (Matilde). J. Inter. Sci. Vigne Vine, 34: 49-55.

Omar, A. H. and A. Abdel-Kawi (2000). Optimal bud load for Thompson Seedless grapevine. J. Agric. Sci. Mansoura Univ., 25(9): 5769.

Phadung, T., S. Nilnond, L. Phavaphutanon and S. Thongpae (2005). Effects of irrigation and mulching materials on growth, yield and berry quality of 'Perlette' grape. Proceedings of $43^{\text {rd }}$ Kasetsart University Annual Conference, Thailand, 1-4 February. Subject: Plants, 459-466.

Reynolds, A. G., D. A. Wardle and A. P. Naylor (1996). Impact of training system, vine spacing, and basal leaf removal on riesling, vine performance, berry composition, canopy microclimate and vineyard labour requirements. Am. J. Enol. Vitis., 47(1): 6376.

Rodriguez-Lovelle, B., J. P. Soyer and C. Molot (2000). Incidence of permanent grass cover on grapevine phenological evolution and grape berry ripening. Acta Horticulturae, 526: 241-248.

Shahein, A. H., M. H. Osman and S. A. Asiha (1998). Effect of pruning levels on yield and fruit quality of Flame Seedless and Ruby Seedless grapevine cultivars. Alex. Agric. Res., 43(2): 229.

Shrestha, G. K., S. Nilnond, L. Phavaphutanon, N. Juntawong and C. Sukumalandana (2000). Influence of plastic roof on fruit quality and yield of 'Beauty Seedless' grape during dry and rainy seasons. Kasetsart J. Natural Sci., 34(2): 179-189.

Smart, R. E. (1985). Principles of grapevine canopy microclimate manipulation with implication for yield and quality: a review. Am. J. Enol. Vitis., 36: 230-239. 
Trambouze, W. and M. Voltz (2001). Measurement and modeling the transpiration of a Mediterranean vineyard. Agric. For. Meteorol., 107(2): 153-166.

Vox, G., E. Schettini, G. S. Mugnozzal, L. Palma, L. Tarricone and G. Gentilesco (2012). Influence on vine production of innovative covering plastic films. Proceedings International Conference of Agricultural Engineering, Valencia, 8-12.07

Vox, G., E. Schettini, G. S. Mugnozza, L. Tarricone, G. Gentilesco and L. Palma (2014). Crimson Seedless table grape grown under plastic film: ecophysiological parameters and grape characteristics as affected by the irrigation volume. Proceedings International Conference of Agricultural Engineering, Zurich, 06-10.07.2014www.eurageng.eu

Winkler, A. J., J. A. Cook, W. M. Kilewer and L. A. Lider (1974). General Viticulture. Uni. Calif. Press, Berkeley, CA., 710.

Winkel, T. and S. Rambal (1990). Stomatal conductance of some grapevines growing in the fields under Mediterranean environment. Agric. For. Metereol., 51: 107-121.

\section{تأثير التغطية البلاستيكية المختلفة ومواعيد التقليم على المحصول و مكوناته في عنب المائدة صنف (سوبريور)

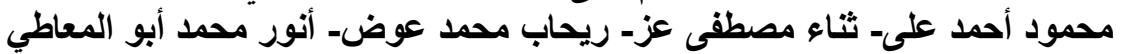

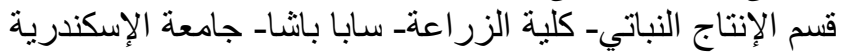

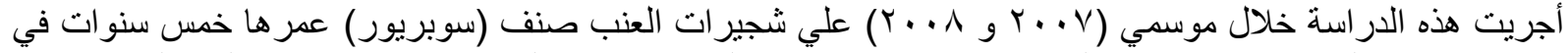

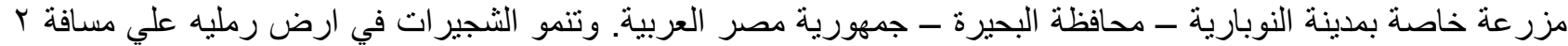

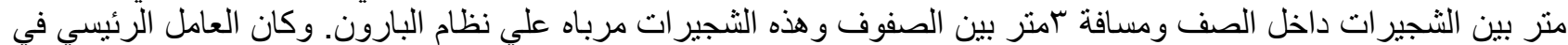

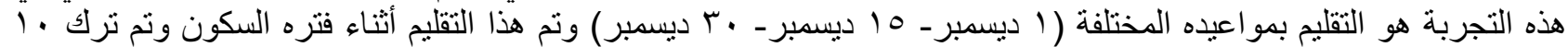

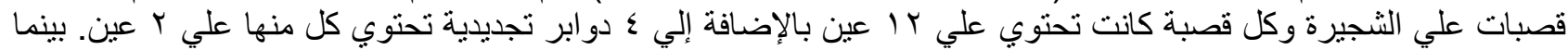

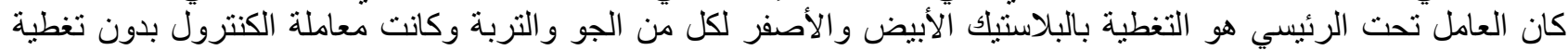

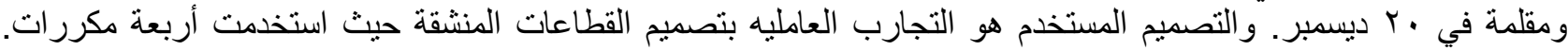

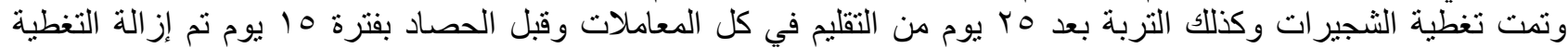

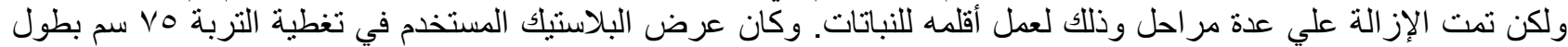

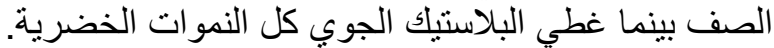

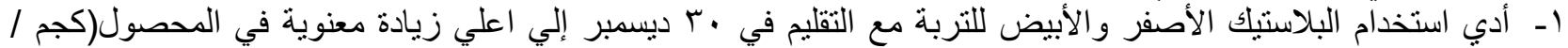

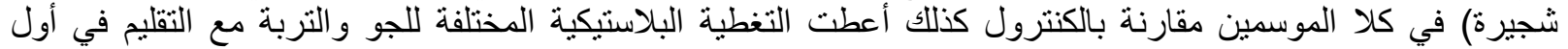

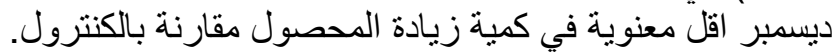

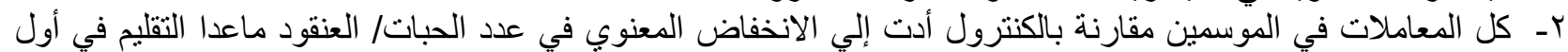

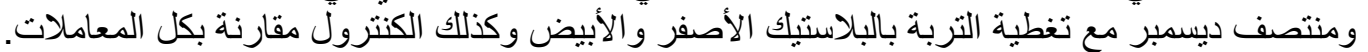

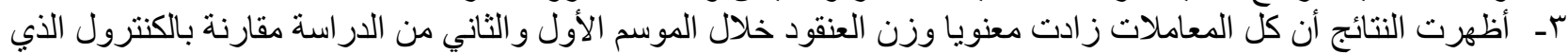

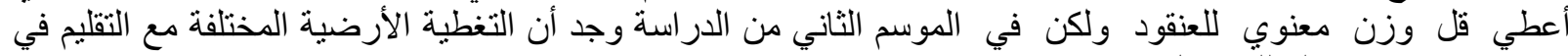
1

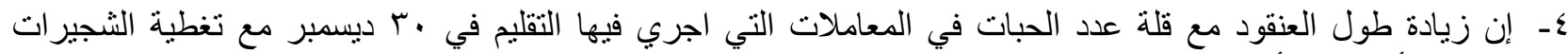

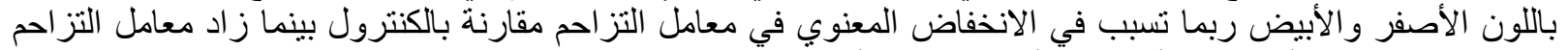

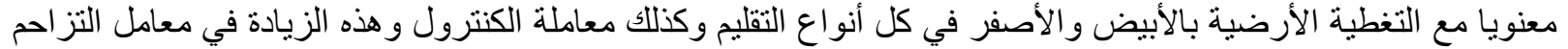

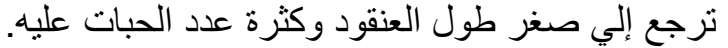

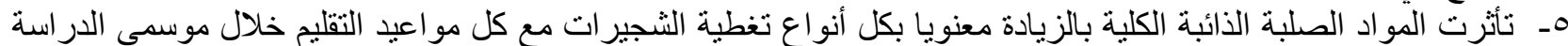

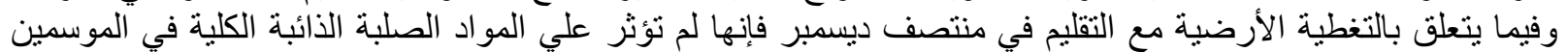

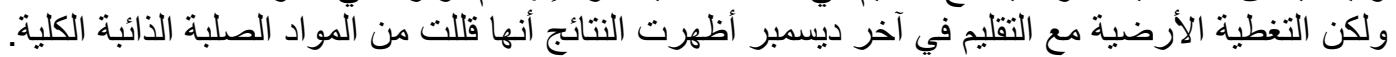

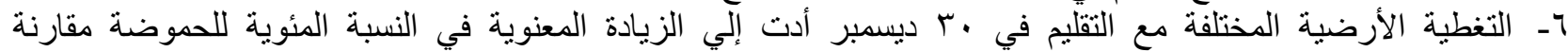

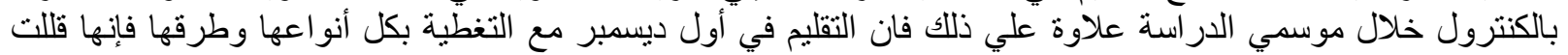

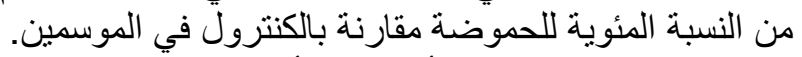

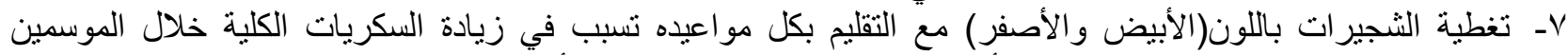

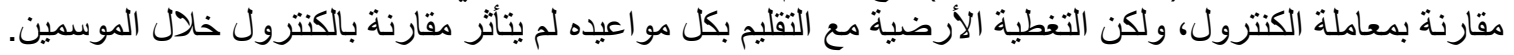

